\title{
Corrosion mechanisms in ADI parts
}

\section{Amadeo Daniel Sosa, Caren Soledad Rosales, Roberto Enrique Boeri \& Silvia Noemí Simison}

To cite this article: Amadeo Daniel Sosa, Caren Soledad Rosales, Roberto Enrique Boeri \& Silvia Noemí Simison (2016): Corrosion mechanisms in ADI parts, International Journal of Cast Metals Research

To link to this article: http://dx.doi.org/10.1080/13640461.2015.1106784

\section{曲 Published online: 01 Mar 2016.}

\section{Submit your article to this journal $\widetilde{ }$}

Џ Article views: 3

Q View related articles $\sqsubset$

View Crossmark data ¿ 


\title{
Corrosion mechanisms in ADI parts
}

\author{
Amadeo Daniel Sosa ${ }^{*_{1}}$, Caren Soledad Rosales ${ }^{2}$, Roberto Enrique Boeri ${ }^{1}$ and \\ Silvia Noemí Simison ${ }^{3}$
}

\author{
The objective of this research is to study the influence of microstructure and grinding on the corrosion \\ resistance of $\mathrm{ADI}$ in salt water. Immersion and electrochemical tests were performed on samples \\ austempered at two different temperatures and ground. The results indicate that the dissolution rate \\ increases as the nodule count does, and it is also affected by the microstructure and by the surface \\ changes introduced during grinding. A porous layer is formed on ADI-corroded surface due to the \\ selective dissolution of ferrite, and a preferential dissolution of the matrix around graphite is noticeable. \\ Ground surfaces are less corrosion resistant than polished ones.
}

Keywords: Austempered ductile iron, Corrosion, Selective dissolution, Ausferrite, Ground surfaces, Plastic strain

\section{Introduction}

Ductile iron (DI) is a candidate material when low manufacturing cost, recyclable and reliable mechanical parts are needed. ${ }^{1}$ It also offers an excellent rate of weight per unit of yield strength comparable with more expensive light alloys. Mechanical properties of DI can be widely changed by heat treatment. The high ductility ferritic irons provide elongation in the range $18-30 \%$, with tensile strengths equivalent to those found in low carbon steel, while austempered ductile iron (ADI) can have tensile strengths exceeding $1600 \mathrm{MPa}$.

The ADI is austempered to obtain a matrix formed by a fine mixture of acicular ferrite and retained austenite. Austempering involves heating to $860-930^{\circ} \mathrm{C}$, followed by rapid cooling into an isothermal bath held at $240-380{ }^{\circ} \mathrm{C}$, where the material remains usually for 30-120 min. Different strength grades can be obtained using different austempering temperatures. These thermal cycles were extensively studied and using proper procedures, the results were found to be very consistent. Even considering the heat treatments, production costs do not exceed that of treated steels with similar mechanical properties.

The ADI parts are common in equipment mounts, pumps and engines exposed to marine condition. When considering thin wall parts, the higher surface-to-volume ratio makes surface properties essential for quality and service performance, particularly when such parts are to be used in corrosive environments. For a given chemical composition, the number of graphite nodules per unit volume increases as the wall thickness decreases. The nodule count (NC) is used to characterize the density of nodules on a given surface, expressed in units per square millimetre. Significant differences in NC can be found comparing conventional to thin wall castings $(<4 \mathrm{~mm})$. The raise in nucleation rate due to higher cooling rate also

${ }^{1}$ Metallurgy Division INTEMA, National University of Mar del Plata, CONICET, Mar del Plata, Argentina,

${ }^{2}$ School of Engineering, National University de Mar del Plata, Mar del Plata, Argentina,

${ }^{3}$ Corrosion Division INTEMA, National University of Mar del Plata, CONICET, Mar del Plata, Argentina

*Corresponding author, email adsosa@fi.mdp.edu.ar leads to a decrease in grain size and produces changes in the microsegregation profile. ${ }^{2}$

Despite the growth of ADI applications, there is scarce information on its behaviour on corrosive media. ${ }^{3-8}$ Some authors studied the corrosion process in multiphase metallic alloys, but the information available on the influence of microstructure and segregation profiles on DI surface reactivity in general is limited and contradictory. The preferential dissolution of ferrite from pearlite was reported for ferritic-pearlitic steels and it is related to galvanic effects. ${ }^{9}$ Other authors ${ }^{5}$ studied the performance of cast iron in various flow conditions and concluded that independently from the graphite morphology, the attack mechanism is dealloying, called graphitic corrosion, which implies preferential dissolution of the matrix around graphite. Surendranathan and Hebra ${ }^{3}$ analyzed the influence of heat treatment on corrosion resistance and concluded that the resistance of the various microconstituents could be ordered as follows: graphite $>$ ferrite $>$ pearlite-ferrite $>$ pearlite. Hemanth ${ }^{4}$ studied the effect of $1-2.5 \%$ $\mathrm{Ni}$ addition for different microstructures and found that the corrosion resistance increased both with increasing Ni content and cooling rates. The beneficial effect of higher cooling rates is related to a greater content of carbides, but this explanation could not be appropriate for the ADI since carbides are dissolved during austenitizing prior to austempering.

When restrictive dimensional tolerances or shape accuracy are required, high-precision machining processes such as grinding are used. Surface grinding is the most common finish machining process employed and involves abrasive chip formation, a process that produces a great amount of heat and leads to plastic deformations that modify material surface properties. Due to machining processes, mechanical-thermal effects (i.e. distortion, type and magnitude of residual stresses, roughness, plastic deformation and hardness variation) take place on the surface and subsurface of the affected layers. Their magnitude could reduce loading capacity, wear behaviour, fatigue and corrosion resistance. In a previous work, ${ }^{8}$ the authors studied the effect of $\mathrm{NC}$ and grinding variables on surface reactivity of thin-wall ferritic 
DI. The results indicated that surface reactivity increases with higher NC and residual plastic strain.

The objective of the present work is to study the effect of austempering temperature, $\mathrm{NC}$ and surface modification by grinding, on the corrosion resistance of the ADI in salt water.

\section{Experimental methods}

The DI melts used in the present study were prepared in a $55-\mathrm{kg}$ medium frequency induction furnace. Steel scrap and foundry returns were used as raw materials. The melt was heated up to $1540{ }^{\circ} \mathrm{C}$ before pouring. Nodularization was carried out using the sandwich method adding $1.5 \mathrm{Wt} \%$ of Fe$\mathrm{Si}-\mathrm{Mg}(6 \% \mathrm{Mg}-\mathrm{Ce})$. The melt was inoculated with $0.6 \mathrm{Wt} \%$ $\mathrm{Fe}-\mathrm{Si}(75 \% \mathrm{Si})$ in a separate ladle. A Baird DV6 spectrometer was used to characterize the chemical composition of the melt. The chemical composition $(\%-\mathrm{Wt})$ of the melt was $\mathrm{C}=3.3$, $\mathrm{Si}=3.56, \mathrm{Cu}=0.64, \mathrm{Ni}=0.5, \mathrm{Mn}=0.12, \mathrm{Mg}=0.04, p=0.03$, $\mathrm{S}=0.01, \mathrm{Ce}<0.01, \mathrm{Ti}=0.01, \mathrm{Mo}=0.01$ and $\mathrm{Fe}$ balance. The carbon equivalent, calculated as: $\mathrm{CE}=\mathrm{C}+(\mathrm{Si}+\mathrm{P}) / 3$, was slightly hypereutectic $(\mathrm{CE}=4.49)$. Several 2 - and 4-mm-thick plates and also 12.7- and 25.4-mm Y blocks (ASTM A395) were cast in sand moulds in order to obtain samples with $\mathrm{NC}$ ranging from 150 to $1700 \mathrm{nod} / \mathrm{mm}^{2}$. The moulds were made by using AFS-60 silica sand and alkyd resin as a binder. In all cases the nodularity ranged between 90 and 95\% (ASTM A247).

Prismatic samples were cut and squared off to dimensions of $100 \times 12.5 \times 2 \mathrm{~mm}$ under low-energy cutting conditions. After heat treatments and grinding, the samples were sectioned to obtain 25-mm-length coupons. Finally, the samples were manually polished using $\mathrm{SiC}$ abrasive paper ranging from 100 to 600 grit.

All samples were austenitized at $910^{\circ} \mathrm{C}$ for $1 \mathrm{~h}$. After that, two batches were austempered in a salt bath for $45 \mathrm{~min}$ at 280 or $360{ }^{\circ} \mathrm{C}$, called ADI280 and ADI360, respectively. These austempering temperatures promote ADI Grades 1400-110002 and 900-650-09 (ASTM A897 M06), respectively, which are extensively used in actual parts production and have high wear resistance or high toughness.

Microstructures and corroded surfaces were observed and analyzed by optical and scanning electron microscopy with dispersive X-ray spectrometer. Conventional polishing techniques and etching with nital $(2 \%)$ were employed.

The thickness of the corroded layers was determined by digital image analysis. To do so, transversal cuts were made on the specimens. Then, the specimens of each batch were mounted with their faces aligned at $90^{\circ}$ angle to the observation plane, and finally polished to carry out metallographic observations.

The X-ray diffraction patterns (XRD) corresponding to the different $\{\mathrm{hk} l\}$ reflections of ferrite and austenite phases were measured in corroded and non-corroded ADI samples to estimate the amount of oxides, ferrite, austenite and its carbon content. Graphite-monochromated $\mathrm{Co}-\mathrm{K} \alpha$ radiation $(\lambda=0.1789 \mathrm{~nm})$ was the option of choice for such measurement. The X-ray tube was operated at $40 \mathrm{kV}$ and $30 \mathrm{~mA}$. Three XRD intensity patterns versus $2 \theta$ plots were obtained for each ADI sample by scanning in the range of $32^{\circ}$ to $62^{\circ}$ with a $2 \theta$ step of $0.05^{\circ}$ and $0.05 \mathrm{~s}$ by step. Powder Cell software developed by Kraus and Nolze, ${ }^{10}$ for peak profile refinement was applied to analyze the XRD patterns and to obtain peak positions and intensities as well as austenite volume fraction and its lattice parameter 'a'. Finally, the per cent of austenite carbon content (\%) was estimated by applying the equation $^{11}: a=3.555+0.044 \mathrm{C} \%$. Table 1 lists the characteristics of the batches and samples.

To evaluate the effect of the surface changes introduced during grinding, conventional straight surface grinding operations were carried out on a set of ADI280 samples (Figure 1). Semi-roughing conditions were employed and applied to different $\mathrm{NC}$ samples. Work speed values $(\mathrm{Vw})$, depth of cut per pass $(p)$ and wheel speed (Vs) were as follows: $\mathrm{Vw}=28 \mathrm{~m} /$ $\min , p=0.03 \mathrm{~mm}$ and $\mathrm{Vs}=20 \mathrm{~m} / \mathrm{s}$. For each test, three grinding passes along the longitudinal direction of the workpiece were performed, employing a commercial vitrified wheel identified as IC36/46/j5v9. ${ }^{12}$ Before each test, the wheel was trued and dressed using a single-point diamond. The workpieces were fixed to the reciprocating table by means of a permanent magnetic chuck, which is a part of the machine.

Electrochemical experiments were conducted at room temperature and atmospheric pressure in a three-electrode cell. A saturated calomel electrode (SCE) was employed as the reference electrode and a platinum spiral wire as the counter electrode. The samples were pressed against the bottom of the cell and sealed using an O-ring. The resulting working electrode area was $0.401 \mathrm{~cm}^{2}$. A $3.5 \% \mathrm{Wt} \% \mathrm{NaCl}$ air-saturated solution was used.

Linear polarization resistance $(\mathrm{Rp})$ was measured on polished samples by polarizing the working electrode $\pm 0.010 \mathrm{~V}$ versus corrosion potential (Ecorr) with a sweep rate of $1.10 \mathrm{E}^{-3} \mathrm{~V} / \mathrm{s}$.

To characterize the reactivity of the subsurface layers, chronoamperometric assays were performed at $+0.8 \mathrm{~V}$ (SCE) during $20 \mathrm{~min}$. Metal loss was calculated for polished samples using Faraday's law, ${ }^{13}$ considering that the metallic exposed area is diminished by graphite fraction. ${ }^{8}$

Immersion tests were performed on polished and ground surfaces of the ADI280 samples. The samples were submerged and hold during 8, 16, 24 and 60 days on a $3.5 \% \mathrm{Wt}$ $\mathrm{NaCl}$ air-saturated solution.

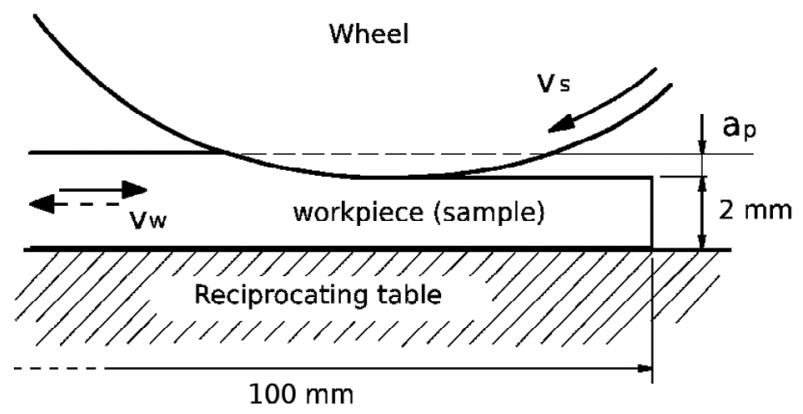

1 Wheel-workpiece contact geometry

Table 1 Characteristics of samples sets

\begin{tabular}{|c|c|c|c|c|c|c|}
\hline Sample & $\begin{array}{c}\text { NC range [nod/ } \\
\left.\mathrm{mm}^{2}\right]\end{array}$ & $\begin{array}{c}\text { Austenitizing } \\
\text { Temperature }\left[{ }^{\circ} \mathrm{C}\right]\end{array}$ & $\begin{array}{c}\text { Austempering } \\
\text { Temperature }\left[{ }^{\circ} \mathrm{C}\right]\end{array}$ & Hardness [HRc] & $\begin{array}{c}\text { Austenite } \\
\text { content [\%] }\end{array}$ & $\begin{array}{l}\text { Austenite carbon } \\
\text { content [\%] }\end{array}$ \\
\hline ADI280 & $150-1700$ & 910 & 280 & $42-46$ & $14.2-19.5$ & $0.169 \pm 0.002$ \\
\hline ADI360 & $150-1700$ & 910 & 360 & $33-35$ & $27.2-34.5$ & $0.174 \pm 0.003$ \\
\hline
\end{tabular}


Before metal loss determinations, tests samples were dry blasted with $\mathrm{SiC}$ particles in a pressurized air flow in order to remove weakly adhered surface products. The attacked profile (metal loss) was measured for all samples by means of image digital analysis. Blank tests were performed on non-corroded samples and no thickness variation was found.

\section{Results and discussion}

Figure 2 shows the microstructure of the samples. In the ascast condition (Figure $2 a$ ), the metal matrix consists of bull's eye ferrite and pearlite. After austempering, Figures $2 b$ and $2 c$, the matrix is formed by a fine mixture of ferrite and austenite. Note that the microstructure is more refined in the ADI280, which correlates with its higher hardness (Table 1). The hardness, microstructure fineness, retained austenite volume fraction and austenite carbon content are consistent with previous works. ${ }^{14}$
All the tested samples showed almost generalized corrosion with a deeper attack around graphite nodules. No pits or cracks were found as reported in the literature ${ }^{15}$ Figure 3 corresponds to a top view of the corrosion surface of a corroded ADI360. The surface was rinsed with distilled water and soft brushed in order to extract loosely adhered corrosion products. It can be observed that corrosion is homogenous but some phase is selectively attacked. A notch was made in the back surface of a corroded sample and then an impact load was applied in order to obtain a fracture surface (Figure 4). In the left side, a flake-like morphology can be observed produced by the preferential dissolution of one phase. The attack progresses leaving a porous layer that surrounds the graphite nodules producing their detachment, although keeping a minimum of structural cohesion. This particular morphology of attack makes electrochemical techniques not suitable for assessing the severity of the corrosion attack because such techniques assume that the analyzed area remains constant

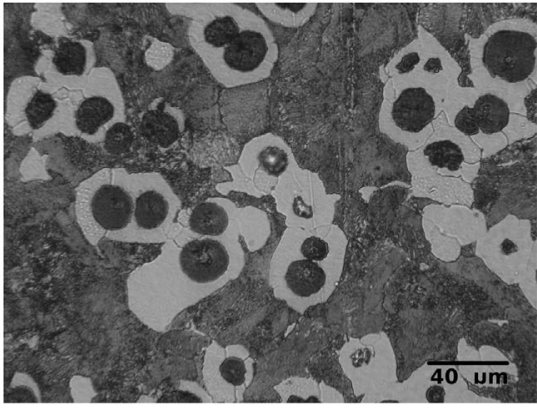

(a)

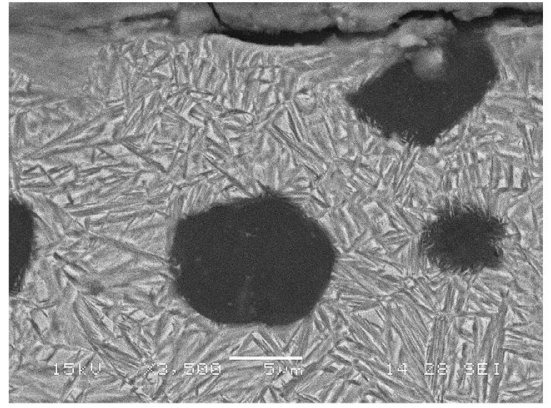

(b)

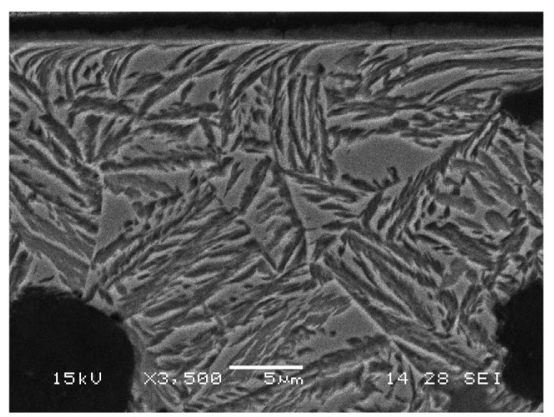

(c)

2 Microstructure of samples: (a) As-cast, (b) ADI280 and (c) ADI360

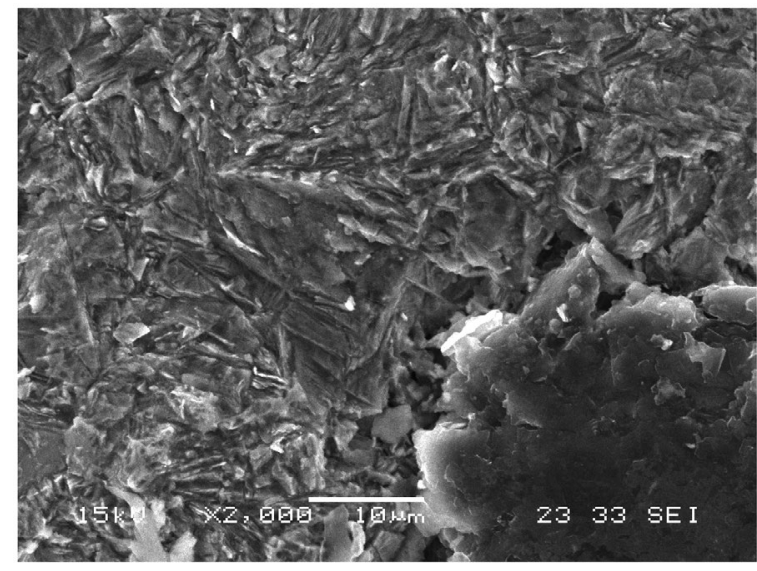

3 Corroded surface of ADI360 and 250-nod $/ \mathrm{mm}^{2}$ sample

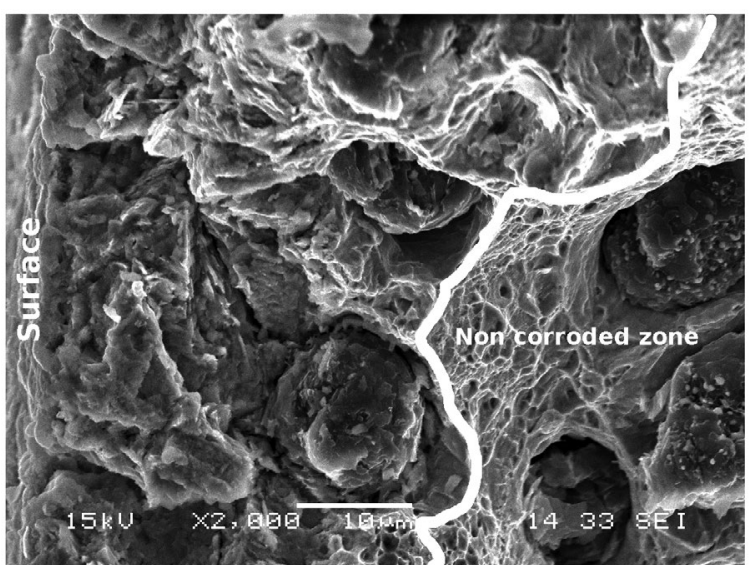

4 Fracture surface of a corroded ADI360 sample made by pre-notched and impact 
during the test and also that the current is uniform in the entire area, which is not the case when there is selective dissolution.

Figures $5 a$ and $5 b$ show transversal cuts of ADI280 and ADI360 mounted and polished after a 60-day immersion in $3.5 \mathrm{Wt} \% \mathrm{NaCl}$ solution. It can be seen that the attack progresses leaving a porous layer of several hundred microns of thickness. The depth of the attack is larger for the ADI360 than for the ADI280. On the weakly oxide layers, normal cracks were produced by expansion of oxides and as a consequence of their drying. Several iron oxides $\left(\mathrm{FeO}, \mathrm{Fe}_{2} \mathrm{O}_{3}, \mathrm{Fe}_{3} \mathrm{O}_{4}\right.$ and $\mathrm{FeFe}_{2} \mathrm{O}_{4}$ ) were identified by analysis of the XRD patterns. At higher magnification (Figure 6), it is clearly seen that the ADI microstructure is revealed due to the selective attack. In order to go deeper, EDS line scans (Figure 7) and in-depth DRX patterns (Figure 8) were performed on corroded samples. It can be seen that the first superficial layers are mainly oxides (cracked part in Figure 5). EDS measurements indicate that the iron content decreases from the bulk towards the surface and the oxygen is detected in all the porous layers. This is an evidence of the metal matrix dissolution and that oxides are occluded in the above-mentioned porous layers. The DRX results in Figure 8 correspond to the ADI360 and were obtained from the original corroded surface and after successive polishing procedures of 25 -micron thickness. It can be seen that the surface is mainly composed of oxides (curve 1). At 25-micron depth (curve 2), the intensity of the austenite peaks is almost the same as that corresponding to the bulk alloy (curve 3), but the ferrite peak is very low which is an evidence of its preferential dissolution. As the examination goes deeper in the porous layer (curve 4), the amount of ferrite increases up to the value corresponding to the non-corroded matrix (curve 3). From Figures $5 a$ and $5 b$, the difference in

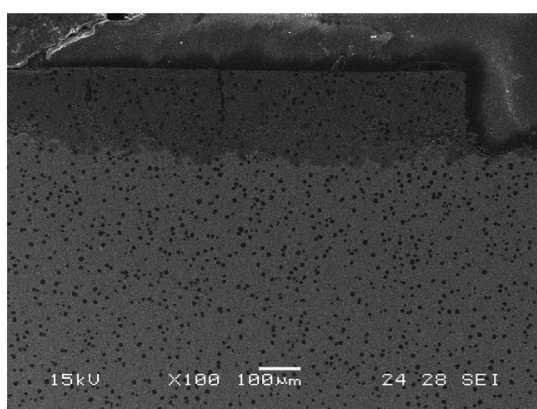

(a)

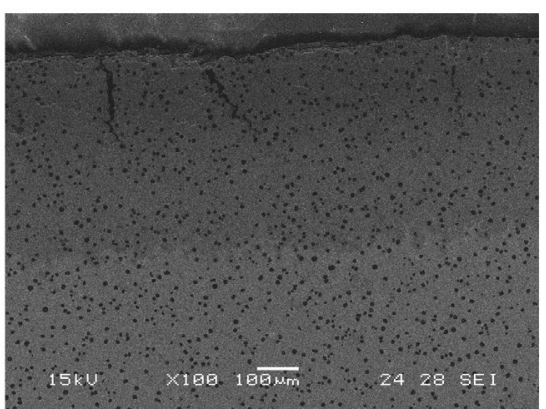

(b)

5 Transverse cuts of ADI280 and ADI360 with $1200 \mathrm{nod} / \mathrm{mm}^{2}$ exposed for 60 days to solution

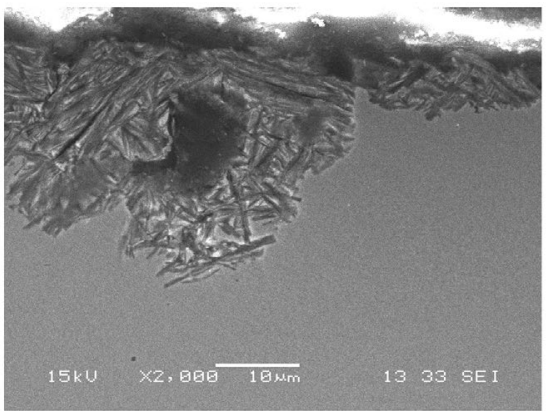

(a)

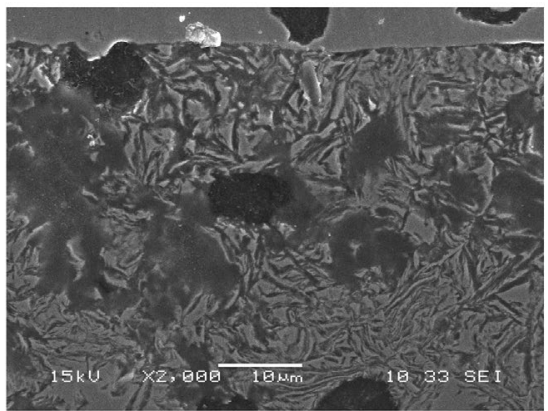

(b)

6 Porous layer on transverse cuts of ADI280 and ADI360 with $1200 \mathrm{nod} / \mathrm{mm}^{2}$ exposed for 60 days to solution
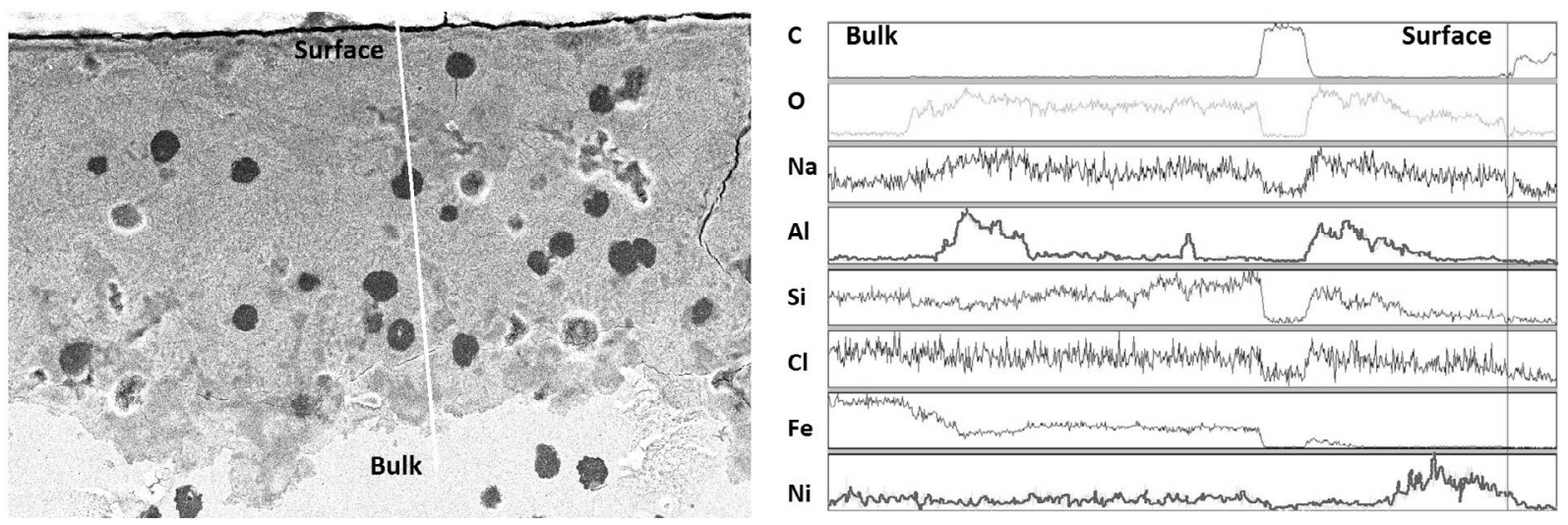

7 Elemental analysis from non-corroded matrix to surface throwing to a nodule 


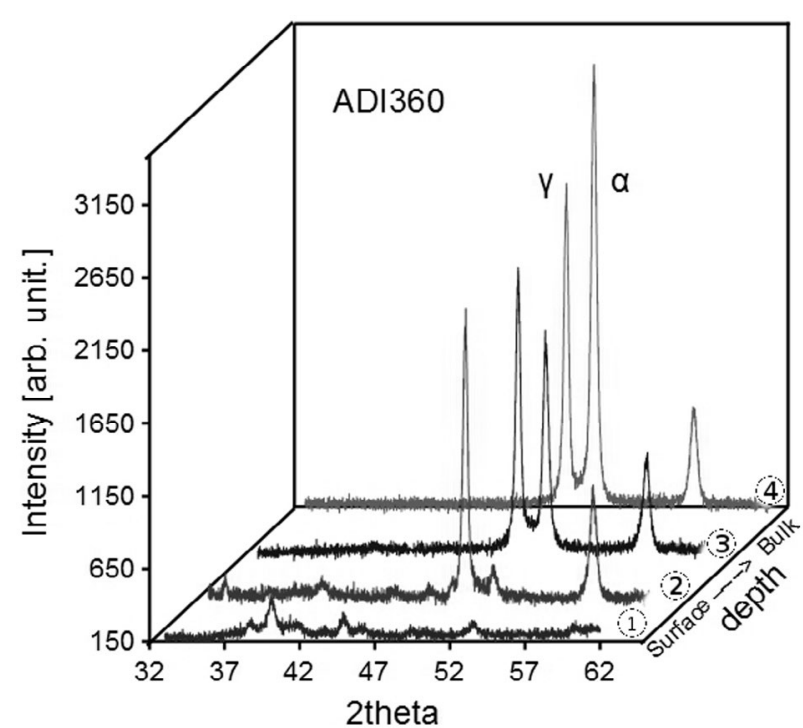

8 DRX patterns for ADI360 at different depths from corroded surface

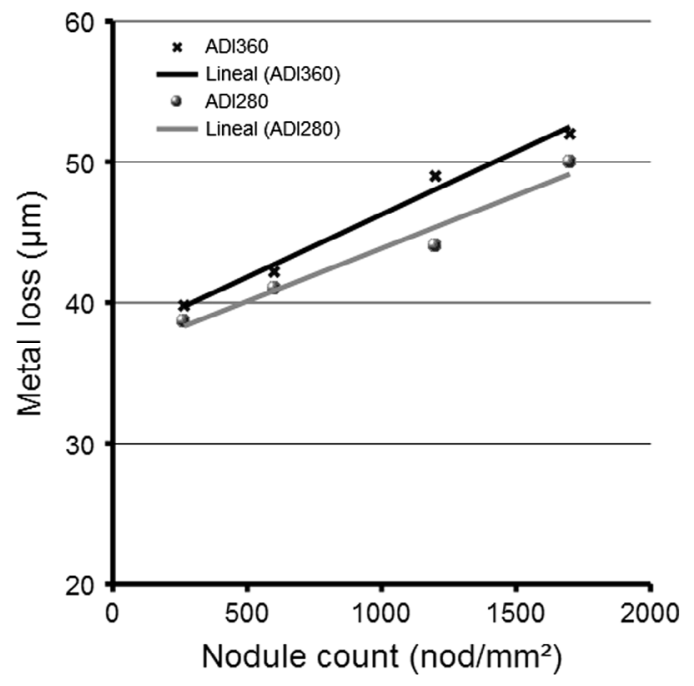

9 Metal loss in chronoamperometric assays for different NCs

the corroded layer thickness can be evaluated. The ADI280 samples present the same morphology of attack but after the first polishing step, the DRX pattern corresponding to the bulk material was obtained, confirming that the damaged layer was thinner than that of the ADI360. The greatest resistance to attack shown by the ADI280 samples could be related to its finer microstructure. Upon dissolution of ferrite phase, paths for transporting ions would be narrower, making it difficult for corrosion to advance.

Metal loss results from chronoamperometric assays are shown in Figure 9. After the test, the samples were air blasted and the corroded thickness was measured. In all cases, the electrochemical results underestimate the depth of the corrosion attack. As was previously reported for ferritic DI, ${ }^{8} \mathrm{NC}$ diminishes the corrosion resistance. The increase in the corrosion rate could be due to the increase in the surface area of graphite for higher amount of nodules, which influences negatively the galvanic couple effect with the surrounding matrix.

The effect of grinding on metal loss is shown in Figure 10 for the ADI280 samples. It can be observed that the metal loss

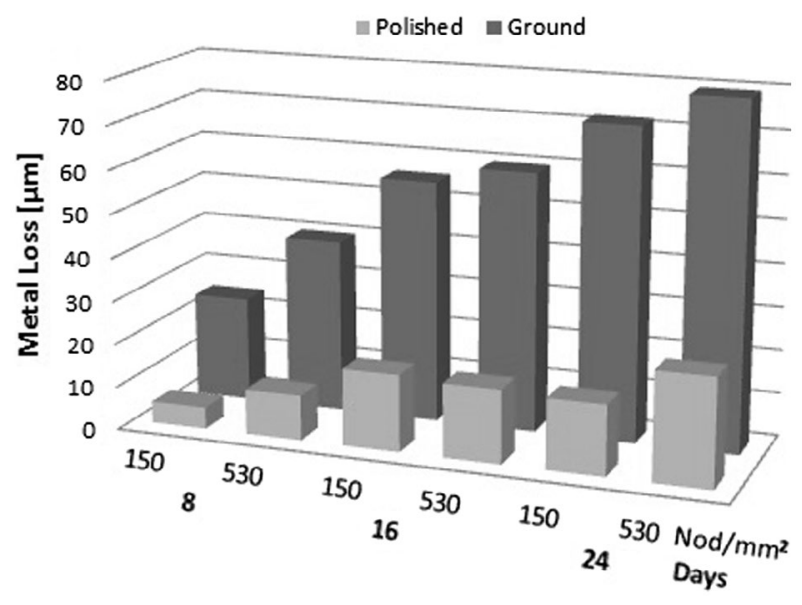

10 Comparison of metal loss for polished and ground surfaces for ADI280 samples

during the first 24 days of immersion is higher for ground surfaces than for the polished ones. This behaviour has the same trend in the ADI360 samples. According to the literature, ${ }^{8,16,17}$ the stored strain energy in the distorted layer induces an increase in the surface reactivity of the deformed alloys. The thickness of the deformed layer depends on the machining conditions/variables and in the alloy nature, and it can reach up to 150 microns under the surface. As already mentioned, if the attack is phase selective, then the electrochemical tests normally used to assess corrosion rate are not appropriate to evaluate this particular corrosion morphology, giving underestimated values.

More work is being carried out in INTEMA at present in order to obtain a better understanding of the corrosion mechanism of the ADI and on the effect of the surface modification introduced by the machining process.

\section{Conclusions}

A singular attack morphology was found on the ADI samples. A porous layer is formed on the corroded surface due to selective dissolution of ferrite phase. This layer could be easily removed, leading to higher attack depths than those that can be appreciated from the top view of corroded surfaces.

Under the experimental conditions used in this work, it was found that the corrosion resistance is dependent on the matrix microstructure, $\mathrm{NC}$ and surface preparation. It can be remarked that:

1. For polished surfaces, the ADI280 is more resistant than the ADI360.

2. For both ADI microstructures, the corrosion rate increases as NC does. Grinding produces a higher surface reactivity due to the stored strain energy in the deformed layers. The electrochemical tests normally used to assess corrosion rate underestimate the metal loss in this particular corrosion morphology.

\section{Disclosure statement}

No potential conflict of interest was reported by the authors.

\section{References}

1. Habil, K. Herfurth, N. Ketscher and A. Huppertz: ' Tech. Analysis of energy demand in foundries and realization of material and energy saving through castings', Commun. of the 64 the World Foundry Congress, Paris, France, 2000 . 
2. J. M. Borrajo, R. A. Martínez, R. E. Boeri and J. A. Sikora: 'Shape and count of free graphite particles in thin wall ductile iron castings', ISIJ Int., 2002, 42, 257-263.

3. A. Surendranathan and K. Hebra: 'Study of corrosion behaviour of ductile iron by electrochemical polarisation techniques', Trans. Indian Inst. Met., 1998, 51, 373-378

4. J. Hemanth: 'The solidification and corrosion behaviour of austempered chilled ductile iron', J. Mater. Process. Technol., 2000, 101, 159-166.

5. H. M. Shalaby, S. Attari, W. T. Riad and V. K. Gouda: 'Erosion-corrosion behavior of some cast alloys in seawater', Corrosion, 1992, 48, 206-217.

6. L. Masud, R. Martínez, S. Simison and R. Boeri: 'Embrittlement of austempered ductile iron on contact with water - testing under applied potential', J. Mater. Sci., 2003, 38, 2971-2977.

7. R. Martinez, S. Simison and R. Boeri: 'Environmentally assistad embrittlement of ADI by contact with liquids', Int. J. Cast Met. Res., 2003, 16, 251-256.

8. A. Sosa, M. Echeverría, O. Moncada and S. Simison: 'Surface reactivity of thin wall ferritic ductile iron. The effect of nodule count and grinding variables', Mater. Lett., 2008, 62, 100-102.

9. D. A. López, T. Pérez and S. Simison: 'The influence of microstructure and chemical composition of carbon and low alloy steels in $\mathrm{CO}^{2}$ corrosion. A state-of-the-art appraisal', Mater. Des., 2003, 24, 561-575.
10. W. Kraus and G. Nolze: 'Powder Cell 2.3 version' 1998, CPD Newsletter, 20, 274.

11. B. D. Cullity: 'Elements of X-ray diffraction', 508; 1974, Reading, MA, Wesley.

12. Machinability data center: 'Machining data handbook', 3rd edn, Vol. 2, 1029; 1987, Cincinnati, OH, MDC.

13. D. A. Jones: 'Principles and prevention of corrosion' 1996, New York, Prentice Hall.

14. A. D. Sosa, M. D. Echeverría, O. J. Moncada, N. Míngolo and J. A. Sikora: 'Influence of nodule count on residual stresses and distortion in thin wall ductile iron plates of different matrices', J. Mater. Process. Technol., 2009, 209 (15-16), 5545-5551.

15. Q. Z. Cai, B. K. Wei and Y. Tanaka: 'Fatigue properties of austempered ductile iron (ADI) in water environment', Acta Metall. Sinica., 2004, 17 (2), 122-130.

16. E. M. Gutman, G. Solovioff and D. Eliezer: 'The mechanochemical behaviour of type 316L stainless steel', Corros. Sci., 1996, 38, 1141-1145.

17. J. Xie, A. T. Alpas and D. O. Northwood: 'Mechano-electrochemical effect between erosion and corrosion', J. Mater. Sci., 2003, 38, 4849-4856. 